\title{
High Planting Density Reduces Productivity and Quality of Mechanized Concord Juice Grapes
}

\author{
Markus Keller ${ }^{1 *}$ and Lynn J. Mills ${ }^{1}$
}

\begin{abstract}
The choice of planting density is a key decision for grapegrowers to make before vineyard establishment, with long-term implications. The field trial described here, with drip-irrigated, machine-pruned Concord juice grapes, tested the effects of two between-row distances $(2.44 \mathrm{~m}$ and $2.74 \mathrm{~m})$ and four within-row distances $(0.91$, $1.83,2.74$, and $3.66 \mathrm{~m}$ ), resulting in planting densities ranging from 997 to $4485 \mathrm{vines} / \mathrm{ha}$, on yield formation and fruit composition. Canopy size, yield components, and fruit composition were measured over six years, starting in year 3 after planting. While in the first cropping season the yield with $0.91 \mathrm{~m}$ and $1.83 \mathrm{~m}$ vine spacing (11.8 t/ha) was twice that with $2.74 \mathrm{~m}$ and $3.66 \mathrm{~m}(5.6 \mathrm{t} / \mathrm{ha})$, on average over the five subsequent years, the yield of $0.91-\mathrm{m}$ vines was $38 \%$ lower (18.2 t/ha) than at the other planting distances $(29.2 \mathrm{t} / \mathrm{ha})$. During the last four years, the average yield of vines planted with $2.44 \mathrm{~m}$ between rows was $2 \mathrm{t} / \mathrm{ha}$ greater than that at $2.74 \mathrm{~m}$. The yield potential and fruit quality of closely spaced vines $(0.91 \mathrm{~m})$ was compromised by their vigorous growth, high canopy density, and poor microclimate, which resulted in fewer clusters/vine, fewer berries/cluster, lower cluster weights, and more bunchstem necrosis. Leaf death in the canopy interior was associated with nutrient remobilization and high potassium and $\mathrm{pH}$ in the juice from $0.91-\mathrm{m}$ vines. Juice total soluble solids, titratable acidity, and color remained unaffected by planting density. These results show that planting juice grapes at high density in irrigated and highly mechanized vineyards is detrimental to both cropping potential and fruit quality.
\end{abstract}

Key words: canopy size, fruit composition, juice grapes, planting density, yield components

Planting density, or the number of vines per unit of land surface area and their arrangement between and within rows, is the only vineyard yield component that is established at planting and remains essentially unchanged for the lifespan of most vineyards. It influences other yield components, such as the number of buds and shoots per vine, which in turn drive the number of clusters per vine and may affect the number of berries per cluster and berry weight (Keller et al. 2004, 2015a, Reynolds and Vanden Heuvel 2009). Because of its long-term implications, the choice of planting density is a key decision for growers to make before vineyard establishment. However, surprisingly little scientific work has been conducted to support the decision-making process. In many regions, the "standard" planting density has remained unchanged for decades or even centuries, and the choice is often driven by tradition, regional regulations, equipment constraints, or even myth.

\footnotetext{
${ }^{1}$ Department of Horticulture, Washington State University, Irrigated Agriculture Research and Extension Center, Prosser, WA 99350.

*Corresponding author (mkeller@wsu.edu)

Acknowledgments: This work was funded by the Washington State Concord Grape Research Council and the USDA National Institute of Food and Agriculture (Hatch project 1000186). The authors thank Alan Kawakami and Maria Mireles for technical assistance and Wyckoff Farms for in-kind support for vineyard establishment and maintenance.

Manuscript submitted April 2021, revised June 2021, accepted June 2021

This is an open access article distributed under the CC BY license (https:// creativecommons.org/licenses/by/4.0/).

By downloading and/or receiving this article, you agree to the Disclaimer of Warranties and Liability. The full statement of the Disclaimers is available at http://www.ajevonline.org/content/proprietary-rights-notice-ajev-online. If you do not agree to the Disclaimers, do not download and/or accept this article. doi: 10.5344/ajev.2021.21014
}

It is often assumed that greater planting density increases competition among vines for resources and thus decreases shoot growth and yield per vine, while increasing crop yield per unit land area (e.g., Mullins et al. 1992 and literature therein). Evidence for this competition hypothesis, however, is limited and based mainly on measurements of leaf area and/or pruning weight per vine. Some studies found inconsistent effects of vine spacing on pruning weight (Reynolds and Wardle 1994) or found that pruning weight per vine decreased as vine spacing decreased but increased when expressed per unit canopy length (Reynolds et al. 1996, 2004a, 2004b). Other studies reported increased shoot number, leaf area, cluster number, and yield per unit canopy length with decreasing vine spacing (Hedberg and Raison 1982, Bernizzoni et al. 2009). Unpruned plants of Vitis species in the wild can grow to very large size and potentially produce fruit for hundreds of years, even in the face of intense competition from trees and other species (Keller 2020). Similarly, minimally pruned cultivated grapevines can remain productive for decades when appropriate management practices are applied (Clingeleffer 1984, Possingham 1994, Poni et al. 2016).

Planting density trials are often also trials of pruning severity because bud number per vine increases as vine spacing increases (Shaulis and Kimball 1955). Grapevines adjust to increased bud number by decreasing the percentages of budbreak and fruit set and by decreasing berry growth (Possingham 1994, Miller and Howell 1998, Intrieri et al. 2001). Research on pruning severity, including manual and mechanical pruning strategies, for American juice grapes has been conducted in both cool-humid and warm-dry regions with vines that were either non-irrigated, furrow-irrigated, or overhead sprinkler-irrigated (Morris and Cawthon 1981, 
Miller and Howell 1998, Keller et al. 2004, Bates and Morris 2009). This research found that in very cool growing seasons, the high yields of mechanically- or minimally-pruned vines were occasionally associated with insufficient fruit maturity by harvest. Meanwhile, mounting issues with spring and summer drought in the western United States over the last two decades have led to gradual and ongoing conversion of juice grape vineyards to drip irrigation. Changes in precipitation patterns associated with global climate change are of particular concern for Washington's Yakima Valley, where a large portion of United States juice grape production is located. The annual precipitation of $\sim 200 \mathrm{~mm}$ makes crop production dependent on irrigation fed by snowmelt in the Cascade Range. However, peak flows of the Yakima River are shifting from May/June to February and overall irrigation water availability is declining (Elsner et al. 2010). At the same time, warming temperatures are driving more rapid evapotranspiration rates from vineyards and other crops, which further increases the risk of summer drought in the region. Growers generally keep juice grapes well irrigated, as they are trying to maximize crop production (e.g., Keller et al. 2004). Owing to their large canopy, such vines use as much as three times more water than do deficit-irrigated winegrapes (Tarara and Ferguson 2006). Consequently, the long-term productivity of high-yielding, drip-irrigated juice grapes under continued mechanical pruning remains unknown.

The objective of this study was to identify the optimal planting distance for fully mechanized juice grape production in drip-irrigated vineyards, with the aim of maximizing profits for growers. In manually balance-pruned juice grapes in upstate New York, yield per unit vineyard area increased slightly as the planting density increased, and a density of 1481 to 1728 vines/ha was found to be ideal to maximize the cropping potential (Shaulis and Kimball 1955). We hypothesized that the cropping potential of large, machine-pruned vines is reached earlier and remains less variable among years when vines are spaced more closely together. Our underlying assumptions were that closely spaced vines (i) fill the cordon more quickly, offering a faster return on investment; and (ii) develop a greater mass of permanent organs per unit land area, which should allow these vines to access stored nutrient reserves for fruit production and ripening to balance episodes of environmental stress (Koblet et al. 1994, Keller et al. 2015b). Based on this premise, we established a juice grape vineyard with two different between-row distances and four within-row distances, including the regional industry standard of $2.74 \mathrm{~m}$ between rows and $1.83 \mathrm{~m}$ within rows, and monitored canopy size, yield components, and fruit composition for six years, beginning in the third year after planting.

\section{Materials and Methods}

Vineyard site and experimental design. The 3.2-ha vineyard block was planted in 2003 with own-rooted, certified clone 6 Concord grapes at the Roza unit of Washington State University's Irrigated Agriculture Research and Extension Center $\left(46.29^{\circ} \mathrm{N} ; 119.74^{\circ} \mathrm{W}, 365 \mathrm{~m}\right.$ asl). Concord is an interspecific hybrid cultivar with Vitis labrusca L. and Vitis vinifera L. ancestry (Huber et al. 2016). Overall site topography is a $<2 \%$ north-to-south slope with 124 -m rows running north to south. The soil type is predominantly Warden silt loam ( $\mathrm{pH}$ 7.2; volumetric water content at field capacity, FC, $22.7 \% \mathrm{v} / \mathrm{v}$; permanent wilting point, PWP, 7.1\%) with a small section of Burke silt loam (pH 7.9; FC 21.9\%; PWP 6.5\%), with $<1 \%$ organic matter (https://websoilsurvey.sc.egov.usda. gov). Soil depth to a caliche layer over basalt varies from 50 to $120 \mathrm{~cm}$. The trellis system consisted of wooden posts alternating with two steel posts, with two vines between posts and a single, high-tensile cordon wire at $1.83 \mathrm{~m}$. No foliage wires were installed. Immediately after planting, a permanent midrow cover of resident vegetation was allowed to develop; it generally went dormant in summer and was not controlled apart from occasional mowing, while a $1.2-\mathrm{m}$ herbicide strip was maintained in the rows during the growing season. Other pesticides were not applied in this vineyard. Six access tubes were installed to a depth of $90 \mathrm{~cm}$ (soil depth permitting) across the trial area to monitor soil moisture using a neutron probe (503 DR Hydroprobe; CPN International). Drip irrigation was supplied using $18-\mathrm{mm}$ driplines with $3.6-\mathrm{L} / \mathrm{hr}$ emitters spaced at $0.91 \mathrm{~m}$. Irrigation water was applied weekly or twice weekly as needed to maintain soil moisture above $15 \%$ and avoid plant water stress, which was assessed visually (i.e., continued shoot growth, absence of leaf wilting or yellowing). Nitrogen fertilizer, in the form of UAN-32, was applied by fertigation through the drip irrigation system. In 2004, $7 \mathrm{~kg}$ $\mathrm{N} /$ ha was applied at the six-leaf stage. The fertilizer rate was increased to $45 \mathrm{~kg} \mathrm{~N} / \mathrm{ha}$ in 2005 and then to $66 \mathrm{~kg} \mathrm{~N} / \mathrm{ha}$ in 2009 to account for greater canopy size and yield as the vines matured. From 2005 onward, fertilizer applications were split equally between the six-leaf stage, bloom, and fruit set.

Young vines were protected with milk cartons and trained up to the cordon wire using baler twine strung between the top of the original cutting and the wire. Cordon establishment began in 2004; cordons were trained unilaterally for vines planted at a distance of $0.91 \mathrm{~m}$ and bilaterally for all other vines. All vines were manually pruned to canes of five to six buds each in 2005 and 2006; cane numbers varied depending on vine size. Mechanical pruning started in 2007 and consisted of hedging $30 \mathrm{~cm}$ on either side of the cordon wire and skirting $30 \mathrm{~cm}$ below the wire; no pruning was done above the wire to retain as many fruitful buds as possible. Bud numbers were then adjusted manually to a maximum of 70 buds per meter of row in 2007 and 2008. From 2009 onward, manual pruning was limited to minimal touch-up only; pruners were instructed to cut off occasional low-hanging canes while walking without stopping. The growing shoots were allowed to hang under the weight of the developing fruit, and no canopy management was applied after winter pruning in this vineyard.

The experiment was designed as a split-plot with two between-row distances ( $2.44 \mathrm{~m}$ and $2.74 \mathrm{~m}$ ) assigned to main plots running the entire row length and four within-row distances $(0.91,1.83,2.74$, and $3.66 \mathrm{~m})$ assigned to subplots in three randomized blocks. This design generated eight unique sets of vine numbers per hectare $(4485,3987,2242,1993$, 
$1495,1329,1121$, and 997), corresponding to a 4.5 -fold range in planting density. Each replicate block consisted of five rows with the between-row spacing arranged such that a middle row was flanked by rows at the same distance, and the withinrow spacing arranged in groups of at least six contiguous vines randomly down the rows but identical across the five rows. Within each treatment replicate, four consecutive data vines were assigned between buffer vines planted at the same spacing. Surrounding data vines on all sides with vines planted at the same distance was important to minimize bias due to potential spacing-related differences in soil or root traits or canopy microclimate. Moreover, data vines were at least five vines away from row ends. All data vines were harvested manually on the same day once the vineyard exceeded an overall total soluble solids (TSS) target of 16 Brix except in 2009 , when the very high yield delayed fruit ripening and harvest was done at 15 Brix. The rest of the vineyard was then machine-harvested by a cooperating grower.

Weather data and plant measurements. Data were collected from 2005 through 2010. Daily weather data were obtained from an on-site AgWeatherNet station (http://weather. wsu.edu) located at the same elevation and $\sim 450 \mathrm{~m}$ to the east of the vineyard. Growing degree days (GDD) for the period 1 April through 31 Oct were estimated from daily maximum and minimum temperatures, applying a base temperature of $10^{\circ} \mathrm{C}$. Vine phenology was monitored in all years and dates of $50 \%$ budbreak, bloom, and veraison, as well as harvest, were recorded.

Yield and its components (clusters per vine, cluster weight, berries per cluster, berry weight) were determined at harvest in all six years. We also attempted to estimate bud fruitfulness (i.e., clusters per shoot) from counts of cluster numbers at harvest and cane numbers before winter pruning. However, because cane counts proved to be error-prone and thus unreliable, cluster numbers per unit row length were used as a proxy for overall vine fruitfulness. A 100-berry sample was collected at harvest from each replicate to measure fruit composition. Juice TSS, titratable acidity (TA), $\mathrm{pH}$, potassium $\left(\mathrm{K}^{+}\right)$, and red color intensity were determined as described (Keller et al. 2004, Harbertson and Harwood 2009). Percent fruit set was determined from 2008 through 2010 for the 2.74 $\mathrm{m}$ row spacing only from counts of flower and berry numbers on three clusters per shoot, one shoot per vine, as previously described (Keller et al. 2001). The flower caps (calyptras) that were collected to estimate fruit set were counted, dried at $60^{\circ} \mathrm{C}$, and weighed. The average cap dry weight (DW) per flower was used as a proxy for flower size, which was then compared with harvest berry weight for berries on the same clusters (Keller et al. 2010).

From 2008 to 2010, canopy dimensions (effective height, width, length) were measured at veraison to estimate the external canopy surface area and the canopy volume, assuming a general box shape typical of the large, hanging-shoot canopy of Concord vines. Light penetration into the fruit zone was measured by inserting an AccuPAR LP-80 ceptometer (Decagon Devices) perpendicular to row direction across the canopy 20 to $30 \mathrm{~cm}$ below the cordon wire, within $30 \mathrm{~min}$ of solar noon on a sunny day at veraison. Fruit-zone light was expressed relative to ambient light above the canopy. Many leaves in the interior of the canopy were dying by veraison, especially in the vines spaced $0.91 \mathrm{~m}$ apart. The extent of leaf death was not quantified, but at $80 \%$ veraison (41 days before harvest) in 2009 we collected 12 sets of six mature leaf blades on the outside of the canopy and 12 sets of six dead leaves in the process of abscission in the canopy interior. The leaves were weighed, and chlorophyll was estimated using a handheld SPAD-502 meter (Minolta) with two measurements per leaf. Then the leaves were thoroughly rinsed with distilled water, dried at $60^{\circ} \mathrm{C}$ to constant weight, weighed again, ground, and sent to a commercial lab (Brookside Laboratories) to analyze leaf carbon, macronutrients, and micronutrients. The leaf samples were supplemented with 100-berry samples collected on the same date for analysis of TSS, TA, $\mathrm{pH}, \mathrm{K}^{+}$, and color. Because pruning weight is not a suitable indicator of vine vigor or size for minimally pruned grapevines, we instead measured trunk diameter $\sim 30 \mathrm{~cm}$ above the vineyard floor in 2010 only.

Data analysis. Data were analyzed using Statistica version 13.5 (TIBCO Software). Effects of within- and between-row spacing (treatments) and year were analyzed by three-way analysis of variance (ANOVA) and $F$-test. Because year $\times$ within-row spacing interactions were often significant, while between-row spacing effects were rarely significant, data from the two row spacings were pooled and within-row spacing data analyzed by one-way ANOVA for each year. Data that were collected only in a single year were analyzed by twoway or one-way ANOVA as appropriate. The $\mathrm{pH}$ values were converted to $\mathrm{H}^{+}$concentrations for data analysis, and means were converted back to $\mathrm{pH}$ for presentation. Duncan's new multiple range test was used for post-hoc means comparisons when treatment or year effects were significant. Associations between key response variables were tested using Pearson product moment correlation analysis.

\section{Results}

Among the six study years, 2010 had the coolest growing season and 2009 the warmest, but the two years differed by only 183 GDD (Table 1). This variation in GDD corresponds to $\mathrm{a}<1{ }^{\circ} \mathrm{C}$ difference in average growing season temperature. Rainfall during the growing season was insignificant except in 2010, which was an unusually cool season with a rainy ripening period. The total annual precipitation varied from only $66 \mathrm{~mm}$ in 2005 to $255 \mathrm{~mm}$ in 2010. Budbreak of the Concord vines in this study generally occurred in mid-April, but in the cool spring of 2008, budbreak was delayed until late April (Table 1). Bloom occurred in the first half of June, varying by 15 days among years, and veraison occurred in the second half of August, varying by 12 days among years. The variation in harvest date was much greater (25 days among years) because that date was determined by a combination of seasonal differences in temperature, crop yield, and equipment availability after the fruit reached the TSS target of 16 Brix.

The average number of clusters per vine across all planting distances increased almost 10-fold from 2005 through 2008 
and then stabilized (Table 2). Average yields increased from $8.7 \mathrm{t} / \mathrm{ha}$ in 2005 to $14.0 \mathrm{t} / \mathrm{ha}$ in $2006,23.1 \mathrm{t} /$ ha in $2007,25.2$ $\mathrm{t} / \mathrm{ha}$ in 2008 , and $42.1 \mathrm{t} / \mathrm{ha}$ in 2009 , before decreasing to 26.8 t/ha in 2010 (Figure 1). The transient cropping peak in 2009 was associated with the transition that year to near-minimal pruning. Higher than average flower numbers and high berry weights resulting in above-average cluster weights also contributed to the high yield in 2009 (Tables 2 and 3). However, there was no evidence of alternate (biennial) bearing in this vineyard. Tracking the crop yields of the 96 individual vines showed that the current-year yield correlated positively with the previous-year yield (Figure 2). After 2006, the correlation coefficient increased and remained stable $(\mathrm{r} \approx 0.78, p<0.001)$ for the next four years. Only slightly lower correlations across years were obtained for cluster numbers per vine after 2006 $(0.68<\mathrm{r}<0.76, p<0.001)$. In other words, those vines that began their "career" with a heavy crop continued to do so and, except in 2010, at an even greater level than before. The greater yield potential of larger vines was further confirmed by the positive relationships between crop yield per vine and both canopy volume (Figure 3A) and exterior canopy surface area (Figure 3B) across years and planting densities and between yield per vine and the trunk diameter measured in 2010 (Figure 4A). Additionally, the trunk diameter also correlated positively with the canopy volume per vine (Figure 4B) and with the vineyard surface area available per vine $(\mathrm{r}=0.74$, $p<0.001, \mathrm{n}=96$ ).

Decreasing the planting density increased the vines' cropping potential or reproductive capacity. This can be visualized by correlating the yield per vine with its available vineyard surface area (within-row spacing $\times$ betweenrow spacing) for each year (Figure 5). On average over the six years, and even though differences were not significant within years (Table 2), the $2.74 \mathrm{~m}$ between-row spacing was associated with $11 \%$ greater yields per vine than the $2.44 \mathrm{~m}$ spacing $(p=0.001)$, which resulted in similar yields per unit vineyard area between the two row distances. However, during the last four years, when the vines were fully productive, the vineyard yield at the $2.44 \mathrm{~m}$ row spacing was $7 \%$ greater $(30.3 \mathrm{t} / \mathrm{ha})$ than that at $2.74 \mathrm{~m}(28.3 \mathrm{t} / \mathrm{ha} ; p=0.045)$. In stark contrast with the row spacing effect $(F=11.2)$, the withinrow spacing effect $(F=350.2)$ as a source of total variation in yield per vine was greater than the year effect $(F=178.5)$, followed in impact by the year $\times$ vine spacing interaction $(F=18.5)$, while the effects of all other interactions were minor by comparison $(F<4)$. Similar ANOVA results were obtained for the number of clusters per vine. The order of vintage and vine spacing as sources of variation was reversed for yield per unit land surface area and for the remaining yield components, but the order of the other factors generally remained the same. The effect on yield of within-row spacing was highly significant across the six years, both at the vine level and at the vineyard area level $(p<0.001)$. The six-year average yield per vine was $4.1,12.9,16.9$, and $24.3 \mathrm{~kg}$ at $0.91,1.83,2.74$, and $3.66 \mathrm{~m}$, respectively. Thus, increasing the within-row spacing four-fold increased crop size (yield per vine) six-fold and crop level (yield per unit row length) by $48 \%$. The equivalent vineyard yield was $17.3,27.2,23.9$, and $25.6 \mathrm{t} / \mathrm{ha}$ at $0.91,1.83,2.74$, and $3.66 \mathrm{~m}$, respectively. Only in 2005, when the 2.74-m and 3.66-m vines had not yet filled their cordon, did the $0.91-\mathrm{m}$ vines bear a similar crop per unit land surface area as the $1.83-\mathrm{m}$ vines. That year the yield at the two higher vine spacings was only $48 \%$ of that at the two lower spacings. The variation among vines was considerably less from 2006 forward than in 2005, reflecting the fact that the vines had now filled the cordon. From 2006 through 2010 , the $0.91-\mathrm{m}$ vines produced on average only $62 \%(17.9 \mathrm{t} / \mathrm{ha})$ of the crop of the vines at the other three within-row spacings ( $29.0 \mathrm{t} / \mathrm{ha} ; p<0.001)$. Over all six years, the greatest vineyard yield was achieved with the standard $1.83 \mathrm{~m}$ vine spacing (Figure 1).

Across all six years, the number of clusters per vine was a far greater driver of vine yield $(\mathrm{r}=0.92, p<0.001, \mathrm{n}=565)$ than was cluster weight $(\mathrm{r}=0.15, p<0.001)$. After 2005, the cluster number per vine increased consistently as vine spacing increased (Table 2). Moreover, vine fruitfulness, estimated as cluster number per unit row length, was high in the $0.91-\mathrm{m}$ and $1.83-\mathrm{m}$ vines in 2005 , when the $2.74-\mathrm{m}$ and $3.66-\mathrm{m}$ vines had not yet filled their allotted cordon space (Table 3 ). Thereafter, however, the fruitfulness of the $0.91-\mathrm{m}$ vines was lower than that of the other vines, indicating that the former had fewer shoots per unit cordon length (i.e., lower budbreak) and/or fewer clusters per shoot (i.e., lower bud fruitfulness). In 2009 and 2010, moreover, the 0.91-m vines lost some of their clusters and portions of individual clusters to bunchstem necrosis (BSN) prior to harvest.

Table 1 Summary of weather conditions and key phenological stages in the Washington State University Concord research vineyard in southeastern Washington. Data were obtained from an AgWeatherNet station located $\sim 450 \mathrm{~m}$ from the vineyard.

\begin{tabular}{|c|c|c|c|c|c|c|c|}
\hline & 2005 & 2006 & 2007 & 2008 & 2009 & 2010 & Long-term \\
\hline Seasonal GDD $\left({ }^{\circ} \mathrm{C}\right)^{\mathrm{a}}$ & 1395 & 1426 & 1343 & 1325 & 1479 & 1296 & 1439 \\
\hline Seasonal precipitation $(\mathrm{mm})$ & 27 & 39 & 47 & 45 & 64 & 143 & 95 \\
\hline Annual precipitation $(\mathrm{mm})$ & 66 & 157 & 152 & 117 & 135 & 255 & 207 \\
\hline Budbreak (DOY) ${ }^{\mathrm{b}}$ & 109 & 107 & 107 & 125 & 110 & 103 & \\
\hline Bloom (DOY) & 154 & 152 & 155 & 167 & 165 & 165 & \\
\hline Veraison (DOY) & 238 & 236 & 229 & 241 & 240 & 240 & \\
\hline Harvest (DOY) & 272 & 262 & 270 & 277 & 287 & 287 & \\
\hline
\end{tabular}

aGrowing degree days (GDD; base $10^{\circ} \mathrm{C}$ ) from 1 April to 31 Oct.

${ }^{\mathrm{b} D O Y}=$ Day of year. 
Despite their low cluster number, the $0.91-\mathrm{m}$ vines generally also had smaller clusters with fewer berries than the vines planted to the higher within-row distances (Table 2). While there was no consistent effect of planting distance on inflorescence size (i.e., flowers per inflorescence), the most narrowly spaced vines had bigger flowers, yet lower fruit set, than the more widely spaced vines (Table 3 ). The percentage fruit set tended to decrease as the number of flowers per inflorescence increased $(\mathrm{r}=-0.52, p<0.001, \mathrm{n}=394)$. Because the average inflorescence size decreased $(p<0.001)$ in the order basal cluster (201 flowers), middle cluster (162 flowers), distal cluster (98 flowers), fruit set increased in that sequence (22, $28,34 \%$ from basal to apical, $p<0.001)$. There was a trend for bigger flowers to become bigger berries, as the flower cap weight (average per cluster) and berry weight were positively correlated $(\mathrm{r}=0.45, p<0.001)$. Nevertheless, planting density did not influence berry weight at harvest consistently (Table 2 ), indicating that other factors were masking the influence of flower size.

Though TSS and TA were not correlated within years, TA tended to be high in years with low TSS and vice versa (Tables 4 and 5). Each year, juice color due to anthocyanins increased markedly as TSS increased $(0.60<\mathrm{r}<0.84, p<0.01)$. This relationship held irrespective of planting distance, indicating that more intense red color was associated with overall riper fruit. Despite a more than 10 -fold range in crop yield among vines, however, TSS was not $(-0.35<\mathrm{r}<0.16, p \geq 0.1)$, and red color intensity inconsistently $(-0.53<\mathrm{r}<0.43, p \geq 0.01)$,

Table 2 Crop yield and its components over six years of mechanically-pruned Concord juice grapes in a vineyard in southeastern Washington planted in 2003 at four different within-row distances and two between-row distances.

\begin{tabular}{|c|c|c|c|c|c|c|}
\hline \multirow[b]{3}{*}{ Year } & \multicolumn{6}{|c|}{ Planting distance $(\mathrm{m})$} \\
\hline & \multicolumn{4}{|c|}{ Within rows } & \multicolumn{2}{|c|}{ Between rows $^{a}$} \\
\hline & 0.91 & 1.83 & 2.74 & 3.66 & 2.44 & 2.74 \\
\hline \multicolumn{7}{|c|}{ Yield (kg/vine) } \\
\hline 2005 & $3.0 \pm 0.4 b^{b}$ & $5.1 \pm 0.8 a b$ & $3.2 \pm 0.8 b$ & $6.4 \pm 1.0 \mathrm{a}$ & $3.6 \pm 0.5$ & $5.2 \pm 0.6$ \\
\hline 2006 & $1.5 \pm 0.2 d$ & $8.3 \pm 0.5 c$ & $10.8 \pm 1.0 b$ & $15.8 \pm 1.2 \mathrm{a}$ & $8.8 \pm 1.0$ & $9.5 \pm 1.0$ \\
\hline 2007 & $3.4 \pm 0.3 d$ & $13.2 \pm 0.6 c$ & $16.8 \pm 1.1 b$ & $25.1 \pm 1.7 \mathrm{a}$ & $13.0 \pm 1.2$ & $16.3 \pm 1.5$ \\
\hline 2008 & $2.8 \pm 0.3 d$ & $15.1 \pm 1.0 \mathrm{c}$ & $20.3 \pm 0.8 b$ & $26.5 \pm 1.6 a$ & $16.2 \pm 1.5$ & $16.2 \pm 1.4$ \\
\hline 2009 & $8.2 \pm 0.7 \mathrm{~d}$ & $21.5 \pm 0.8 c$ & $29.8 \pm 2.1 b$ & $43.8 \pm 2.4 \mathrm{a}$ & $24.4 \pm 2.1$ & $27.2 \pm 2.3$ \\
\hline 2010 & $5.1 \pm 0.6 \mathrm{~d}$ & $13.5 \pm 0.9 c$ & $20.1 \pm 1.0 b$ & $26.8 \pm 1.3 a$ & $16.2 \pm 1.3$ & $16.5 \pm 1.4$ \\
\hline \multicolumn{7}{|c|}{ Clusters per vine } \\
\hline 2005 & $25 \pm 3 b$ & $42 \pm 6 a b$ & $25 \pm 6 b$ & $51 \pm 8 a$ & \multicolumn{2}{|c|}{$36 \pm 3$} \\
\hline 2006 & $23 \pm 3 c$ & $107 \pm 7 b$ & $125 \pm 12 b$ & $185 \pm 13 a$ & \multicolumn{2}{|c|}{$112 \pm 8$} \\
\hline 2007 & $34 \pm 3 d$ & $118 \pm 6 c$ & $151 \pm 10 b$ & $237 \pm 18 a$ & \multicolumn{2}{|c|}{$135 \pm 9$} \\
\hline 2008 & $54 \pm 5 d$ & $214 \pm 11 c$ & $307 \pm 22 b$ & $366 \pm 23 a$ & \multicolumn{2}{|c|}{$234 \pm 15$} \\
\hline 2009 & $91 \pm 8 d$ & $224 \pm 10 c$ & $275 \pm 18 b$ & $428 \pm 23 a$ & \multicolumn{2}{|c|}{$254 \pm 15$} \\
\hline 2010 & $79 \pm 8 d$ & $185 \pm 12 c$ & $288 \pm 18 b$ & $374 \pm 19 a$ & \multicolumn{2}{|c|}{$231 \pm 13$} \\
\hline \multicolumn{7}{|c|}{ Cluster weight (g) } \\
\hline 2005 & $116 \pm 6$ & $118 \pm 7$ & $111 \pm 11$ & $121 \pm 7$ & \multicolumn{2}{|c|}{$117 \pm 4$} \\
\hline 2006 & $64 \pm 4 b$ & $82 \pm 4 a$ & $85 \pm 5 a$ & $83 \pm 3 a$ & \multicolumn{2}{|c|}{$78 \pm 2$} \\
\hline 2007 & $97 \pm 4 b$ & $113 \pm 3 a$ & $112 \pm 3 a$ & $107 \pm 3 a$ & \multicolumn{2}{|c|}{$107 \pm 2$} \\
\hline 2008 & $52 \pm 2 b$ & $72 \pm 4 a$ & $69 \pm 3 a$ & $72 \pm 3 a$ & \multicolumn{2}{|c|}{$66 \pm 2$} \\
\hline 2009 & $91 \pm 4 c$ & $98 \pm 2 b c$ & $109 \pm 4 a$ & $103 \pm 3 a b$ & \multicolumn{2}{|c|}{$100 \pm 2$} \\
\hline 2010 & $63 \pm 3 b$ & $74 \pm 3 a$ & $72 \pm 2 a$ & $73 \pm 2 a$ & \multicolumn{2}{|c|}{$70 \pm 1$} \\
\hline \multicolumn{7}{|c|}{ Berries per cluster } \\
\hline 2005 & $45 \pm 3$ & $45 \pm 2$ & $39 \pm 5$ & $44 \pm 3$ & \multicolumn{2}{|c|}{$43 \pm 2$} \\
\hline 2006 & $26 \pm 2 b$ & $30 \pm 1 a b$ & $33 \pm 2 a$ & $33 \pm 1 \mathrm{a}$ & \multicolumn{2}{|c|}{$31 \pm 1$} \\
\hline 2007 & $35 \pm 3$ & $37 \pm 1$ & $39 \pm 2$ & $35 \pm 2$ & \multicolumn{2}{|c|}{$37 \pm 1$} \\
\hline 2008 & $19 \pm 2 b$ & $29 \pm 2 a$ & $25 \pm 2 a$ & $28 \pm 1 a$ & \multicolumn{2}{|c|}{$26 \pm 1$} \\
\hline 2009 & $32 \pm 2$ & $34 \pm 1$ & $36 \pm 2$ & $37 \pm 2$ & \multicolumn{2}{|c|}{$35 \pm 1$} \\
\hline 2010 & $24 \pm 2 b$ & $29 \pm 1 a$ & $28 \pm 1 a$ & $28 \pm 1 a$ & \multicolumn{2}{|c|}{$27 \pm 1$} \\
\hline \multicolumn{7}{|c|}{ Berry weight (g) } \\
\hline 2005 & $2.6 \pm 0.09$ & $2.6 \pm 0.12$ & $2.9 \pm 0.07$ & $2.9 \pm 0.10$ & & 0.05 \\
\hline 2006 & $2.5 \pm 0.06 b$ & $2.8 \pm 0.08 \mathrm{a}$ & $2.6 \pm 0.05 a b$ & $2.5 \pm 0.04 b$ & & 0.04 \\
\hline 2007 & $2.8 \pm 0.13$ & $3.1 \pm 0.02$ & $2.9 \pm 0.09$ & $3.1 \pm 0.09$ & & 0.05 \\
\hline 2008 & $2.7 \pm 0.11$ & $2.5 \pm 0.13$ & $2.8 \pm 0.12$ & $2.6 \pm 0.09$ & & 0.06 \\
\hline 2009 & $2.8 \pm 0.15$ & $2.9 \pm 0.05$ & $3.0 \pm 0.07$ & $2.8 \pm 0.08$ & & 0.05 \\
\hline 2010 & $2.6 \pm 0.07$ & $2.6 \pm 0.04$ & $2.5 \pm 0.06$ & $2.6 \pm 0.06$ & & 0.03 \\
\hline
\end{tabular}

aValues are listed for both row spacings only when the main effect is significant $(p<0.05)$.

bValues show means \pm SE $(n=24)$. Different letters within rows indicate significant differences by Duncan's new multiple range test $(p<0.05)$; absence of letters indicates no significant difference. 
correlated with yield per vine in any year. Although in most years greater yields were associated with lower juice $\mathrm{K}^{+}$ concentrations $(-0.64<\mathrm{r}<-0.32, p \geq 0.001)$, this apparent "yield effect" was clearly driven by the high- $\mathrm{K}^{+}$juice from the low-yielding, 0.91-m vines. When these vines were excluded from the analysis, all correlations became insignificant $(-0.22<\mathrm{r}<0.29, p \geq 0.23)$.

The planting distance did not influence juice composition in 2005. Juice TSS and color intensity, though variable among years, remained unaffected by planting distance throughout the experiment (Table 4). Between-row spacing also did not influence TA and pH in any year. In 2006, however, the juice from 0.91-m vines had both a higher TA and a higher $\mathrm{pH}$ than the juice from the other vines (Table 5). We therefore measured juice $\mathrm{K}^{+}$in the remaining years to test whether the high $\mathrm{pH}$ was related to high $\mathrm{K}^{+}$concentration. Indeed, both the $\mathrm{pH}$ and $\mathrm{K}^{+}$concentration in the juice were consistently greater in the vines planted at $0.91 \mathrm{~m}$ than in those planted to any other within-row distance (Table 5). Moreover, the $\mathrm{pH}$ correlated with $\mathrm{K}^{+}$both across years $(\mathrm{r}=0.63, p<0.001)$ and within each year, and the $0.91-\mathrm{m}$ vines always clustered near the top of this relationship (Figure 6). In two of those four years, the TA was somewhat correlated with $\mathrm{K}^{+}(\mathrm{r} \leq 0.57, p<0.05)$, but in the other two years, there was no such correlation. Across all years, there was only a very weak correlation between juice $\mathrm{pH}$ and TA $(\mathrm{r}=-0.29, p<0.001)$, but this correlation became stronger $(\mathrm{r}=-0.63, p<0.001)$ when the $0.91-\mathrm{m}$ vines were excluded from the analysis. Moreover, the year with the lowest TA (2005) was also the year with the highest $\mathrm{pH}$, and the year with the highest TA (2008) was the year with the lowest $\mathrm{pH}$ (Table 5). While $\mathrm{K}^{+}$was not measured in 2005 , the $\mathrm{K}^{+} / \mathrm{pH}$ relationship in 2008 differed from that in the other years (Figure 6). Therefore, differences in juice $\mathrm{pH}$ at harvest between growing seasons were mostly driven by differences in TA but modulated by $\mathrm{K}^{+}$, whereas $\mathrm{pH}$ differences at harvest within seasons were mostly driven by differences in $\mathrm{K}^{+}$concentration.

Over the 41-day period from $80 \%$ veraison to harvest in 2009 , berry weight increased $30 \%$ (2.23 to 2.89 g), juice TSS

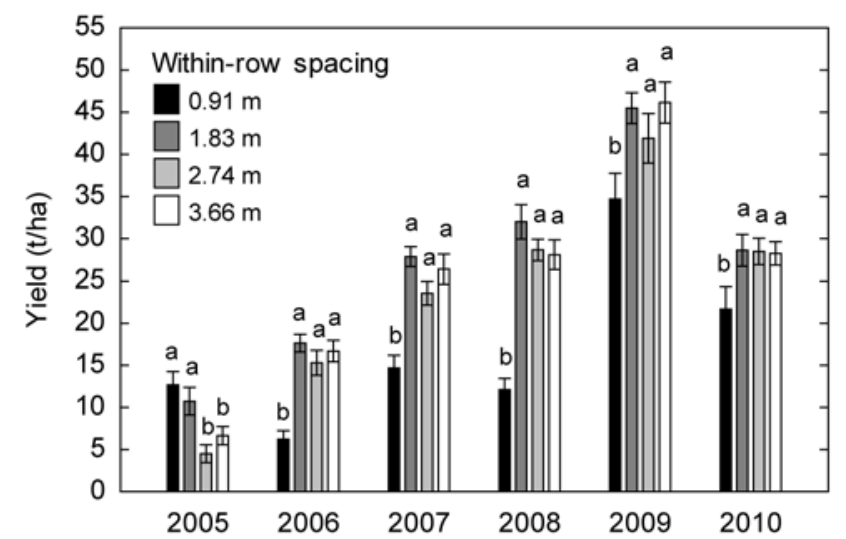

Figure 1 Crop yield over six years of mechanically-pruned Concord juice grapes in a vineyard in southeastern Washington planted in 2003 at four different within-row distances and two between-row distances $(2.44 \mathrm{~m}$ and $2.74 \mathrm{~m}$; data pooled for lack of significant differences). Bars show means \pm SE $(n=24)$. Different letters above bars indicate significant differences within years by Duncan's new multiple range test $(p<0.05)$. increased from 9.2 to 14.8 Brix (108\% increase in the amount of sugar per berry), TA declined $46 \%$ (23.2 to $12.6 \mathrm{~g} / \mathrm{L}), \mathrm{pH}$ increased from 2.99 to 3.37 , red color intensity increased from 0.43 to 0.78 , while $\mathrm{K}^{+}$increased only from $1.2 \mathrm{~g}$ to $1.4 \mathrm{~g} / \mathrm{L}$ $\left(54 \%\right.$ increase in the amount of $\mathrm{K}^{+}$per berry; $\left.p<0.001\right)$. The positive correlation between $\mathrm{K}^{+}$concentration and $\mathrm{pH}$ across the two sampling dates $(\mathrm{r}=0.81, p<0.001, \mathrm{n}=36)$ was even stronger than the negative correlation between TA and $\mathrm{pH}(\mathrm{r}=-0.76, p<0.001)$. A multiple linear regression showed that the variation in TA and $\mathrm{K}^{+}$together accounted for $89 \%$ of the variation in juice $\mathrm{pH}$. However, while the $\mathrm{pH}$ variation between sampling dates was almost equally due to variations in $\mathrm{TA}$ and $\mathrm{K}^{+}$, the $\mathrm{pH}$ variation within dates was almost entirely due to variation in $\mathrm{K}^{+}$. Much of this variation was associated with planting density. Despite similar TSS and TA across within-row distances, the juice from 0.91-m vines had $27 \%$ and $23 \%$ more $\mathrm{K}^{+}$at late veraison and harvest, respectively, than that from the other vines $(p=0.002)$. The corresponding juice $\mathrm{pH}$ was 3.15 and 3.51 in 0.91 -m vines at veraison and harvest, respectively, compared with 2.95 and 3.33 in the other vines $(p<0.001)$. Thus, the differences in $\mathrm{K}^{+}$ concentration and $\mathrm{pH}$ due to vine spacing were already present at $80 \%$ veraison, coinciding with interior leaf senescence, and remained almost constant through harvest.

To explore whether the reduced crop yield and fruit quality at the narrow within-row spacing was related to a change in

Table 3 Vine fruitfulness (clusters per unit row length) over six years and flowering traits over three years of mechanicallypruned Concord juice grapes in a vineyard in southeastern Washington planted in 2003 at four different within-row distances and two between-row distances (data were only collected for the $2.74 \mathrm{~m}$ row spacing).

\begin{tabular}{lcccc}
\hline \multicolumn{5}{c}{ Within-row planting distance (m) } \\
\cline { 2 - 5 } Year & $\mathbf{0 . 9 1}$ & $\mathbf{1 . 8 3}$ & $\mathbf{2 . 7 4}$ & $\mathbf{3 . 6 6}$ \\
\hline \multicolumn{5}{c}{ Vine fruitfulness (clusters/m) } \\
2005 & $28 \pm 3 \mathrm{a}^{\mathrm{a}}$ & $23 \pm 3 \mathrm{a}$ & $9 \pm 2 \mathrm{~b}$ & $14 \pm 2 \mathrm{~b}$ \\
2006 & $25 \pm 4 \mathrm{C}$ & $59 \pm 4 \mathrm{a}$ & $46 \pm 4 \mathrm{~b}$ & $51 \pm 4 \mathrm{ab}$ \\
2007 & $38 \pm 3 \mathrm{~b}$ & $65 \pm 3 \mathrm{a}$ & $55 \pm 4 \mathrm{a}$ & $65 \pm 5 \mathrm{a}$ \\
2008 & $59 \pm 5 \mathrm{~b}$ & $117 \pm 6 \mathrm{a}$ & $112 \pm 8 \mathrm{a}$ & $100 \pm 6 \mathrm{a}$ \\
2009 & $100 \pm 8 \mathrm{~b}$ & $122 \pm 5 \mathrm{a}$ & $100 \pm 6 \mathrm{ab}$ & $117 \pm 6 \mathrm{ab}$ \\
2010 & $86 \pm 9$ & $101 \pm 6$ & $105 \pm 6$ & $102 \pm 5$ \\
Inflorescence size (flowers/cluster) & \\
2008 & $140 \pm 11$ ab & $122 \pm 8 \mathrm{~b}$ & $151 \pm 11 \mathrm{ab}$ & $168 \pm 11 \mathrm{a}$ \\
2009 & $175 \pm 12$ ab & $169 \pm 10 \mathrm{~b}$ & $186 \pm 12 \mathrm{ab}$ & $203 \pm 10 \mathrm{a}$ \\
2010 & $140 \pm 10$ & $122 \pm 9$ & $147 \pm 9$ & $134 \pm 10$ \\
Flower size (mg dry weight/cap) & & \\
2008 & $0.46 \pm 0.01 \mathrm{a}$ & $0.42 \pm 0.01 \mathrm{~b}$ & $0.41 \pm 0.01 \mathrm{~b}$ & $0.43 \pm 0.01 \mathrm{~b}$ \\
2009 & $0.42 \pm 0.01 \mathrm{a}$ & $0.38 \pm 0.01 \mathrm{~b}$ & $0.39 \pm 0.01 \mathrm{~b}$ & $0.38 \pm 0.01 \mathrm{~b}$ \\
2010 & $0.35 \pm 0.01 \mathrm{a}$ & $0.29 \pm 0.01 \mathrm{~b}$ & $0.28 \pm 0.01 \mathrm{~b}$ & $0.29 \pm 0.01 \mathrm{~b}$ \\
Fruit set (\%) & & & \\
2008 & $25 \pm 3 \mathrm{~b}$ & $34 \pm 2 \mathrm{a}$ & $33 \pm 2 \mathrm{a}$ & $29 \pm 2 \mathrm{ab}$ \\
2009 & $23 \pm 2 \mathrm{~b}$ & $26 \pm 2 \mathrm{ab}$ & $29 \pm 2 \mathrm{a}$ & $29 \pm 1 \mathrm{a}$ \\
2010 & $24 \pm 2$ & $27 \pm 2$ & $27 \pm 2$ & $28 \pm 2$ \\
\hline
\end{tabular}

aValues show means \pm SE $(n \geq 23)$. Different letters within rows indicate significant differences by Duncan's new multiple range test $(p<0.05)$; absence of letters indicates no significant difference. 
canopy density, we measured canopy dimensions and light penetration into the fruiting zone in the last three years of this study. The average shoot length (hence the effective canopy height) was $31 \%$ greater, and the canopy width was $29 \%$ greater, at $0.91 \mathrm{~m}$ vine spacing than at the other three planting distances (Table 6). Though both the external canopy surface area and the canopy volume per vine increased as the vine spacing increased, the difference in canopy volume between the $0.91-\mathrm{m}$ and $1.83-\mathrm{m}$ vines was not significant. Because of their greater height and width than the other vines, the 0.91$\mathrm{m}$ vines had a $30 \%$ greater canopy surface area and $68 \%$ greater canopy volume per unit row length, which resulted in a $23 \%$ lower surface-area:volume ratio. On average, only $2 \%$ (36 $\mu \mathrm{mol} / \mathrm{m}^{2} \mathrm{sec}$ ) of ambient light reached the fruiting zone of the $0.91-\mathrm{m}$ vines, compared with $11 \%\left(186 \mu \mathrm{mol} / \mathrm{m}^{2} \mathrm{sec}\right)$ in the other vines. None of these measures of canopy size, density, and microclimate differed among the vines spaced at 1.83 , 2.74 , and $3.66 \mathrm{~m}$ (Table 6). Compared with the strong effect of within-row spacing, the effect of between-row spacing was minor and inconsistent among years (Table 6). The canopy volume correlated closely with the canopy width $(\mathrm{r}=0.94$, $p<0.001, \mathrm{n}=144$ ), and as the canopy width increased from year to year in these machine-pruned vines, so did its volume, decreasing the amount of light in the fruiting zone. Consequently, fruit-zone light correlated inversely with canopy volume each year, but the correlation coefficient decreased over time as the overall size of the canopy increased (Figure 7).

Noticing many dead leaves inside the dense canopy at veraison, we decided in 2009 to sample both live exterior and dead interior leaves for nutrient analysis. The blades of interior leaves weighed (DW) only about one-third of the exterior leaves, were devoid of chlorophyll, and had significantly reduced amounts of carbon and mineral nutrients on a per leaf basis (Table 7). Apart from the complete loss of chlorophyll, the reduction was greatest $(\sim 85 \%)$ for nitrogen, phosphorus, and sulfur, somewhat less ( $\sim 65 \%)$ for carbon, calcium, and manganese, lower still (40 to 55\%) for magnesium, copper, and boron, and least (20 to $27 \%$ ) for zinc, potassium, and iron. This indicates that both organic and inorganic nutrients had been recycled to differing degrees from the interior leaves before they were abscised.

\section{Discussion}

The present study demonstrated that a 4.5 -fold variation in planting density (997 to 4485 vines/ha) of Concord juice grapes has a minor effect on the initial return on investment associated with vineyard establishment but has long-term effects on vine performance in a highly mechanized, dripirrigated vineyard. Vines planted at $0.91 \mathrm{~m}$ within rows and trained to a single-wire trellis did not fill the cordon more quickly than vines planted at the "standard" spacing of $1.83 \mathrm{~m}$, but vines planted $2.74 \mathrm{~m}$ and $3.66 \mathrm{~m}$ apart did take an extra year to reach their full cropping potential. Beginning in their second cropping year, however, there were no differences in vineyard yield and fruit composition among the three higher planting distances, while the vines planted at $0.91 \mathrm{~m}$ consistently produced less fruit of lower quality. Contrary to our

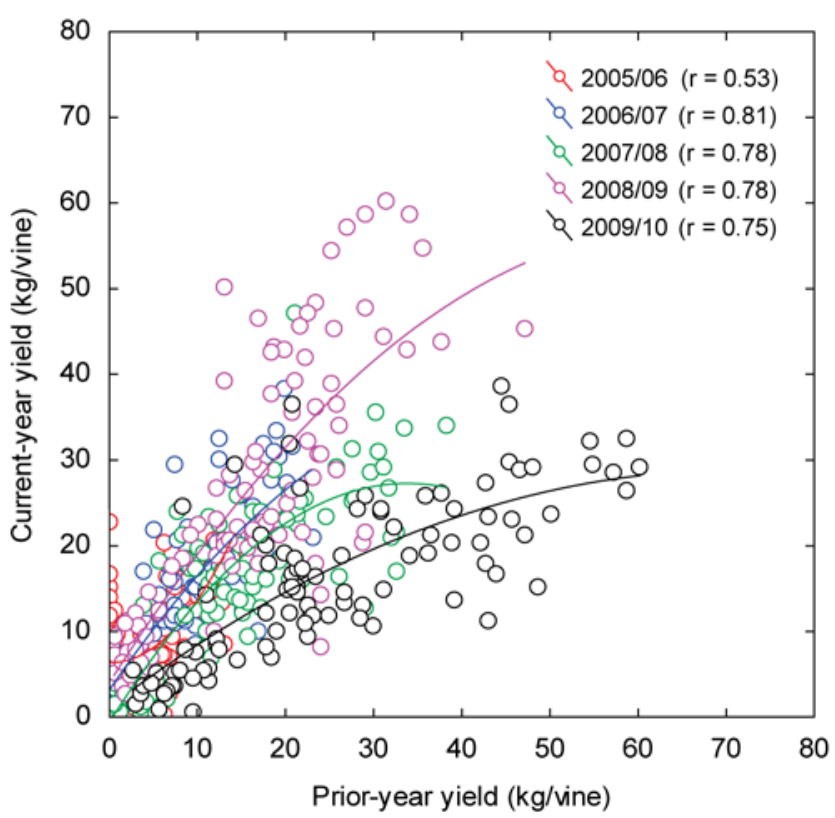

Figure 2 Association over six years between crop yields of the current year and the previous year of mechanically-pruned Concord juice grapes in a vineyard in southeastern Washington planted in 2003. All correlations are significant at $p<0.001(\mathrm{n}=96)$.
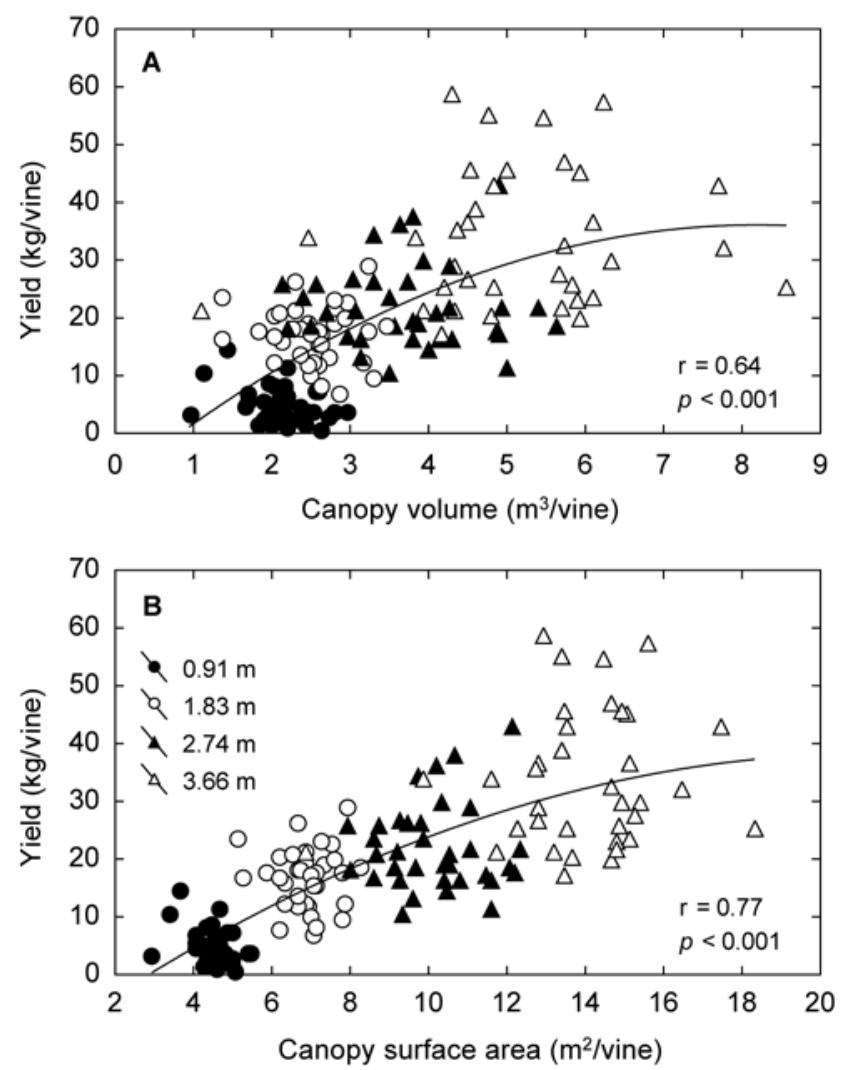

Figure 3 Association between canopy volume and crop yield (A), and between external canopy surface area and crop yield (B) of mechanicallypruned Concord juice grapes in a vineyard in southeastern Washington planted in 2003 at four different within-row distances and two betweenrow distances $(2.44 \mathrm{~m}$ and $2.74 \mathrm{~m})$. Between-row data are pooled for lack of significant differences, and data across years (2008 to 2010) are pooled $(n=144)$. 
initial hypothesis, therefore, high planting density restricted the vines' cropping potential and reduced overall fruit quality. Decreasing the row width from the "standard" $2.74 \mathrm{~m}$ to $2.44 \mathrm{~m}$ between rows had only minor effects on vineyard yield and none on fruit composition. The data presented here indicate that machine-pruned vines adapt to an increase in planting distance by filling their allotted space both aboveground and below-ground, thus minimizing differences in yield per unit land surface area. We also found no evidence of biennial bearing, even at the greatest planting distance $(3.66 \mathrm{~m}$ within rows $\times 2.74 \mathrm{~m}$ between rows, resulting in only 997 vines/ ha), confirming earlier results obtained with large, machinepruned Concord vines in eastern Washington (Keller et al. 2004). Nevertheless, given that the observations reported here were made during the first eight growing seasons, it remains to be seen whether the high yield potential of the widely spaced vines can be sustained over several decades.

Even when planted $3.66 \mathrm{~m}$ apart, the vigorous, drip-irrigated Concord vines in this experiment filled the entire length of available cordon within four to five years after planting, which contrasts with low-vigor, furrow-irrigated Muscat of Alexandria vines in an Australian experiment (Turkington et al. 1980). The trunk diameter measured in the last year of this field trial (year 8 after planting) increased as the within-row planting distance increased, which is consistent
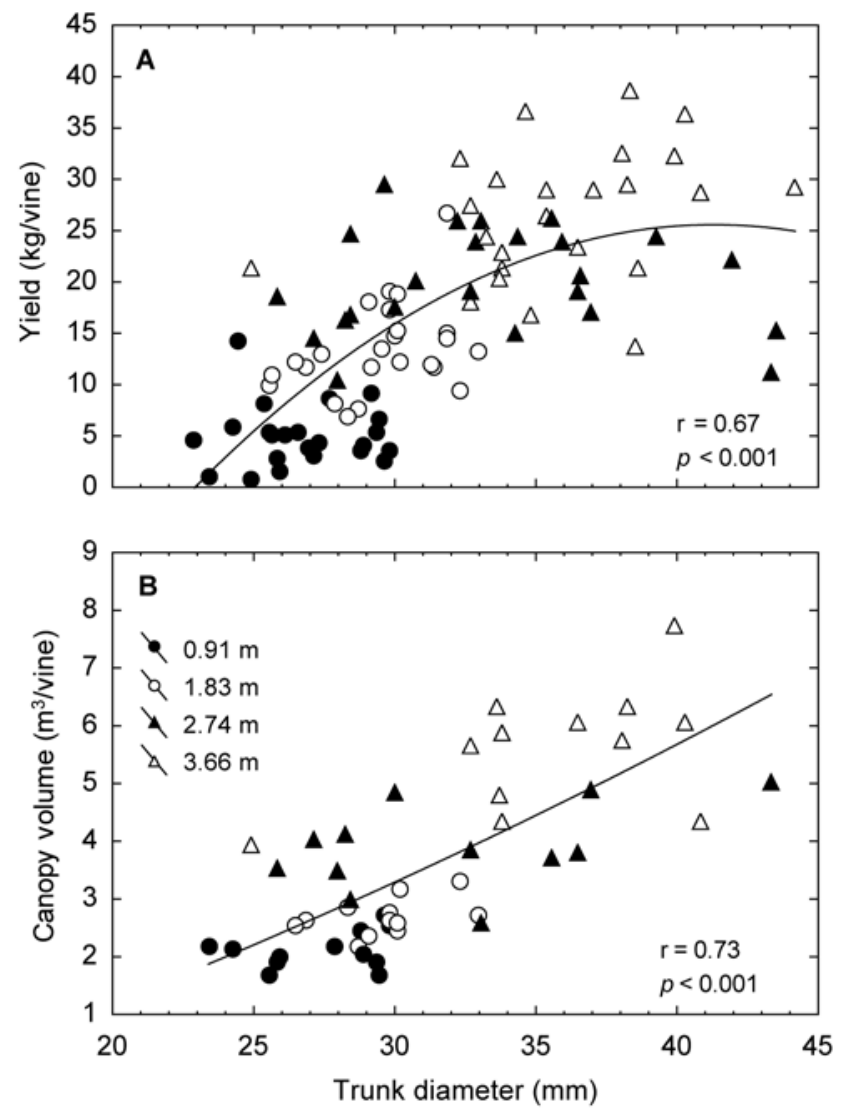

Figure 4 Association between trunk diameter and crop yield (A) and canopy volume (B) of eight-year-old, mechanically-pruned Concord juice grapes in a vineyard in southeastern Washington planted in 2003 at four different within-row distances and two between-row distances. Betweenrow data are pooled for lack of significant differences (A: $n=96 ; B: n=48)$. with results presented for $V$. vinifera winegrapes (Winkler 1959, 1969, Archer and Strauss 1991). We contend that this relationship between trunk diameter and vine spacing should not be interpreted as suggesting that high planting density led to competition among vines for soil resources. Instead, the less densely spaced vines probably adapted by increasing their root and water-transport systems to match the greater water demand of their larger canopy. Hydraulic adaptation to increasing canopy size was previously demonstrated in winegrapes whose bud number was varied while keeping the planting density constant (Keller et al. 2015a). The same study also concluded that hydraulic adaptation is limited, which contributes to the typical decrease in shoot vigor as the shoot number per vine increases.

Despite their thin trunks, the vines planted $0.91 \mathrm{~m}$ apart compensated for their lower bud and shoot numbers by growing more vigorously: by veraison, their shoots were typically 40 to $50 \mathrm{~cm}$ longer than the shoots of all other vines, irrespective of row distance. The shoots of $0.91-\mathrm{m}$ vines continued growing throughout the season, producing many vigorous

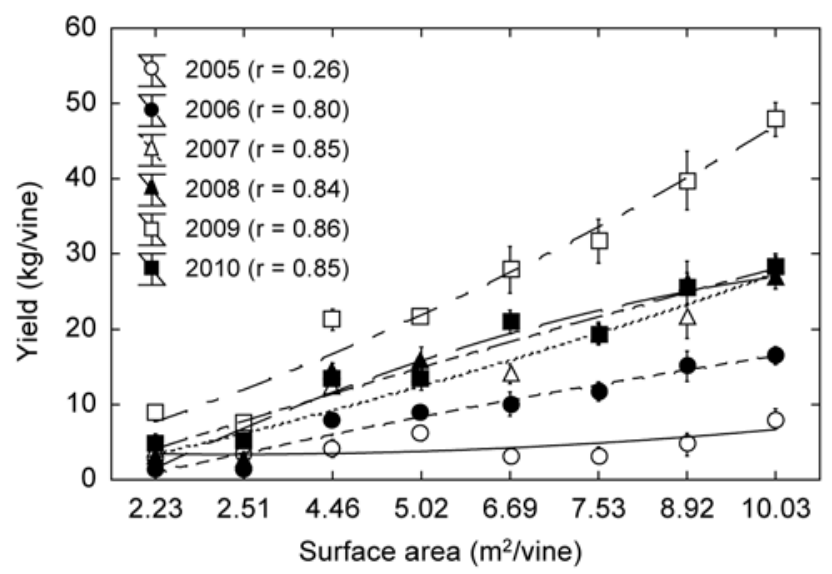

Figure 5 Association over six years between crop yields and vineyard surface area available to each vine of mechanically-pruned Concord juice grapes in a vineyard in southeastern Washington planted in 2003 at four different within-row distances and two between-row distances resulting in eight planting densities corresponding to (from left to right) 4485, 3987, $2242,1993,1495,1329,1121$, and 997 vines/ha. Note: the x-axis is not to scale; correlation coefficients $(r)$ are calculated for the raw data $(n=$ 48 ), not the means; $p=0.01$ in 2005 , all other $p<0.001$.

Table 4 Total soluble solids (TSS) and color intensity over six years in juice from mechanically-pruned Concord juice grapes in a vineyard in southeastern Washington planted in 2003.

\begin{tabular}{ccc}
\hline Year & $\begin{array}{c}\text { TSS } \\
\text { (Brix) }\end{array}$ & $\begin{array}{c}\text { Color } \\
\left(\mathbf{A}_{430+520}\right)\end{array}$ \\
\hline 2005 & $20.2 \pm 0.4 \mathrm{a}^{\mathrm{a}}$ & $0.80 \pm 0.04 \mathrm{a}$ \\
2006 & $18.8 \pm 0.2 \mathrm{~b}$ & $0.69 \pm 0.02 \mathrm{~b}$ \\
2007 & $17.7 \pm 0.2 \mathrm{c}$ & $0.80 \pm 0.04 \mathrm{a}$ \\
2008 & $16.3 \pm 0.2 \mathrm{~d}$ & $0.55 \pm 0.03 \mathrm{c}$ \\
2009 & $14.8 \pm 0.3 \mathrm{e}$ & $0.78 \pm 0.03 \mathrm{a}$ \\
2010 & $17.2 \pm 0.1 \mathrm{c}$ & $0.79 \pm 0.02 \mathrm{a}$ \\
\hline
\end{tabular}

${ }^{a}$ Values show means \pm SE $(n=24)$. Different letters within columns indicate significant differences by Duncan's new multiple range test $(p<0.05)$. Planting density effects are not significant. 
lateral shoots. Their vigorous growth made the canopy of the high-density vines $\sim 30 \mathrm{~cm}$ wider than that at the lower planting densities. The densely planted vines seemed to compete for sunlight and likely activated their shade-avoidance response. Continued leaf formation is typical for grapevines growing under limiting light conditions (Keller and Koblet 1995a, Keller 2020). Consequently, the high-density vines had a larger canopy surface area and greater canopy volume per unit row length than lower-density vines. Light measurements conducted at veraison showed that the light within the fruit zone decreased as the canopy volume increased, indicating that larger, more vigorous canopies were also denser. On average, $\sim 2 \%\left(36 \mu \mathrm{mol} / \mathrm{m}^{2} \mathrm{sec}\right)$ of the ambient light reached the fruit zone of $0.91-\mathrm{m}$ vines, while the fruit zone of the remaining vines received $11 \%\left(186 \mu \mathrm{mol} / \mathrm{m}^{2} \mathrm{sec}\right)$ of ambient light, although this difference seemed to decline over the last three years of the trial. Row spacing, however, had only minor effects on canopy dimensions and on light penetration into the fruit zone. Overall, the mechanical pruning strategy maintained the vines' canopy size at a high and remarkably stable level, and the large canopy size of the $0.91-\mathrm{m}$ vines impeded tractor traffic in the 2.44-m rows.

Because our widely spaced vines produced similar numbers of clusters per unit row length as did the vines planted at the standard within-row spacing of $1.83 \mathrm{~m}$, we did not observe a decrease in crop yield per unit cordon length or land surface area as the vine spacing increased. Unlike in earlier research with $V$. vinifera and interspecific wine and juice grapes, in- cluding Concord (Shaulis and Kimball 1955, Intrieri 1987, Reynolds and Wardle 1994) but similar to another Concord study (Shaulis 1982), the highest planting density in our study compromised the crop yield per unit land surface area. This reduction in yield potential was likely an effect of the poor

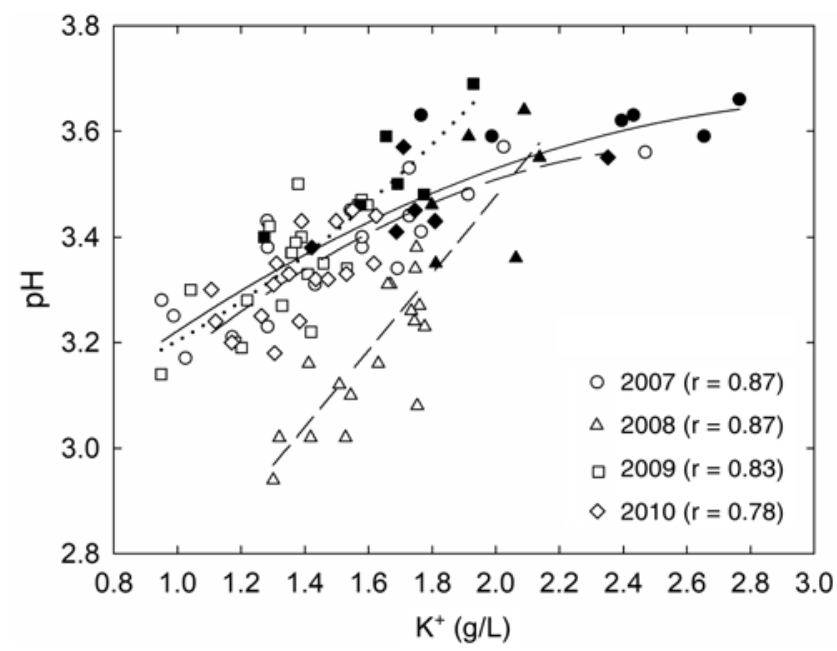

Figure 6 Association over four years between $\mathrm{pH}$ and $\mathrm{K}^{+}$concentration in juice from mechanically-pruned Concord juice grapes in a vineyard in southeastern Washington planted in 2003 at four different withinrow distances (filled symbols represent vines planted at $0.91 \mathrm{~m}$, open symbols represent vines planted at $1.83,2.74$, and $3.66 \mathrm{~m}$ ) and two between-row distances $(2.44 \mathrm{~m}$ and $2.74 \mathrm{~m}$; data pooled for lack of significant differences).

Table 5 Titratable acidity, potassium $\left(\mathrm{K}^{+}\right)$, and $\mathrm{pH}$ over six years in juice from mechanically-pruned Concord juice grapes in a vineyard in southeastern Washington planted in 2003 at four different within-row distances and two between-row distances.

\begin{tabular}{|c|c|c|c|c|c|}
\hline \multirow[b]{3}{*}{ Year } & \multicolumn{5}{|c|}{ Planting distance $(\mathrm{m})$} \\
\hline & \multicolumn{4}{|c|}{ Within rows } & Between rows $^{a}$ \\
\hline & 0.91 & 1.83 & 2.74 & 3.66 & 2.44 \\
\hline \multicolumn{6}{|c|}{ Titratable acidity (g/L) } \\
\hline 2005 & $9.6 \pm 0.4$ & $9.3 \pm 0.2$ & $9.8 \pm 0.2$ & $9.5 \pm 0.2$ & $9.6 \pm 0.1$ \\
\hline 2006 & $12.6 \pm 0.3 a^{b}$ & $11.8 \pm 0.3 b$ & $11.8 \pm 0.1 b$ & $11.8 \pm 0.2 b$ & $12.0 \pm 0.1$ \\
\hline 2007 & $11.0 \pm 0.3$ & $10.7 \pm 0.3$ & $10.4 \pm 0.6$ & $10.7 \pm 0.4$ & $10.7 \pm 0.2$ \\
\hline 2008 & $13.3 \pm 0.4$ & $12.9 \pm 0.3$ & $12.5 \pm 0.5$ & $12.7 \pm 0.3$ & $12.9 \pm 0.2$ \\
\hline 2009 & $13.5 \pm 0.4 a$ & $12.2 \pm 0.1 \mathrm{~b}$ & $12.2 \pm 0.1 \mathrm{~b}$ & $12.6 \pm 0.1 \mathrm{~b}$ & $12.6 \pm 0.2$ \\
\hline 2010 & $13.4 \pm 0.7 \mathrm{a}$ & $11.3 \pm 0.2 b$ & $11.5 \pm 0.4 b$ & $12.0 \pm 0.5 a b$ & $12.0 \pm 0.3$ \\
\hline \multicolumn{6}{|c|}{$\mathrm{K}^{+}(\mathrm{g} / \mathrm{L})$} \\
\hline 2005 & & & Not determined & & \\
\hline 2006 & & & Not determined & & \\
\hline 2007 & $2.33 \pm 0.16 a$ & $1.44 \pm 0.12 b$ & $1.53 \pm 0.15 b$ & $1.60 \pm 0.22 b$ & $1.73 \pm 0.11$ \\
\hline 2008 & $1.97 \pm 0.06 \mathrm{a}$ & $1.64 \pm 0.04 b$ & $1.53 \pm 0.09 b$ & $1.64 \pm 0.07 b$ & $1.70 \pm 0.05$ \\
\hline 2009 & $1.65 \pm 0.09 a$ & $1.29 \pm 0.07 b$ & $1.33 \pm 0.09 b$ & $1.42 \pm 0.06 a b$ & $1.42 \pm 0.05$ \\
\hline 2010 & $1.79 \pm 0.13 a$ & $1.40 \pm 0.03 b$ & $1.34 \pm 0.07 b$ & $1.40 \pm 0.10 \mathrm{~b}$ & $1.49 \pm 0.06$ \\
\hline \multicolumn{6}{|l|}{ pH } \\
\hline 2005 & $3.48 \pm 0.03 a b$ & $3.53 \pm 0.02 a b$ & $3.44 \pm 0.04 b$ & $3.55 \pm 0.03 a$ & $3.50 \pm 0.02$ \\
\hline 2006 & $3.43 \pm 0.01 \mathrm{a}$ & $3.33 \pm 0.03 b$ & $3.32 \pm 0.03 b$ & $3.35 \pm 0.03 a b$ & $3.35 \pm 0.01$ \\
\hline 2007 & $3.62 \pm 0.01 \mathrm{a}$ & $3.36 \pm 0.05 b$ & $3.35 \pm 0.05 b$ & $3.38 \pm 0.05 b$ & $3.41 \pm 0.03$ \\
\hline 2008 & $3.48 \pm 0.05 a$ & $3.17 \pm 0.05 b$ & $3.13 \pm 0.06 b$ & $3.20 \pm 0.07 b$ & $3.23 \pm 0.04$ \\
\hline 2009 & $3.51 \pm 0.04 a$ & $3.31 \pm 0.04 b$ & $3.34 \pm 0.05 b$ & $3.33 \pm 0.05 b$ & $3.37 \pm 0.03$ \\
\hline 2010 & $3.46 \pm 0.03 a$ & $3.32 \pm 0.03 b$ & $3.29 \pm 0.04 b$ & $3.33 \pm 0.04 b$ & $3.35 \pm 0.02$ \\
\hline
\end{tabular}

aThe row spacing effect is not significant.

bValues show means \pm SE $(n=6)$. Different letters within rows indicate significant differences by Duncan's new multiple range test $(p<0.05)$; absence of letters indicates no significant difference. 
canopy microclimate caused by high shoot density and vigor (Hedberg and Raison 1982, Shaulis 1982, Smart et al. 1982a, 1982b, Gladstone and Dokoozlian 2003). The vigorous shoot growth and low light inside the dense canopy of the 0.91-m vines was associated with reduced cluster initiation and fruit set, which resulted in fewer clusters/vine, fewer berries/cluster, and lower cluster weights. BSN, observed in the $0.91-\mathrm{m}$ vines in 2009 and 2010, might also be attributed to carbon starvation due to lack of light and competition from growing shoots (Keller and Koblet 1995b, Keller et al. 2001). The additive effects of these yield components led to a significant loss in crop yield once the vines were fully established. Thus, the yield potential of the high-density vines was compromised by their vigorous growth, high canopy density, and poor microclimate. These vines clearly did not compete for soil water and mineral nutrients; instead, they competed for access to sunlight. Whereas in the first cropping season (year 3 after planting) the vines planted at $0.91 \mathrm{~m}$ and $1.83 \mathrm{~m}$ produced twice the amount of fruit $(11.8 \mathrm{t} / \mathrm{ha})$ than the vines planted at $2.74 \mathrm{~m}$ and $3.66 \mathrm{~m}(5.6 \mathrm{t} / \mathrm{ha})$, on average over the five subsequent years, the $0.91-\mathrm{m}$ vines had $38 \%$ less fruit per unit land surface area (18.2 $\mathrm{t} / \mathrm{ha})$ compared with the other planting distances $(29.2 \mathrm{t} / \mathrm{ha})$. This difference amounted to a cumulative crop loss of $50.2 \mathrm{t} /$ ha over the six study years, which, at a hypothetical average juice grape price of $\$ 200 / t$, would translate into an annual loss in farm income of $\$ 1673 /$ ha.

Table 6 Canopy dimensions and light in the fruit zone at veraison over three years of mechanically-pruned Concord juice grapes in a vineyard in southeastern Washington planted in 2003 at four different within-row distances and two between-row distances.

\begin{tabular}{|c|c|c|c|c|c|c|}
\hline \multirow[b]{3}{*}{ Year } & \multicolumn{6}{|c|}{ Planting distance (m) } \\
\hline & \multicolumn{4}{|c|}{ Within rows } & \multicolumn{2}{|c|}{ Between rows $^{a}$} \\
\hline & 0.91 & 1.83 & 2.74 & 3.66 & 2.44 & 2.74 \\
\hline \multicolumn{7}{|c|}{$\begin{array}{l}\text { Average shoot } \\
\text { length }(\mathrm{cm})\end{array}$} \\
\hline 2008 & $184 \pm 8 a^{b}$ & $131 \pm 4 b$ & $131 \pm 5 b$ & $131 \pm 8 b$ & \multicolumn{2}{|c|}{$144 \pm 5$} \\
\hline 2009 & $184 \pm 6 a$ & $147 \pm 4 b$ & $144 \pm 5 b$ & $146 \pm 4 b$ & \multicolumn{2}{|c|}{$155 \pm 3$} \\
\hline 2010 & $178 \pm 3 a$ & $140 \pm 4 b$ & $135 \pm 5 b$ & $145 \pm 4 b$ & \multicolumn{2}{|c|}{$149 \pm 3$} \\
\hline \multicolumn{7}{|c|}{ Canopy width (cm) } \\
\hline 2008 & $125 \pm 4 a$ & $91 \pm 4 b$ & $90 \pm 5 b$ & $95 \pm 6 b$ & \multicolumn{2}{|c|}{$100 \pm 3$} \\
\hline 2009 & $126 \pm 5 a$ & $97 \pm 3 b$ & $101 \pm 3 b$ & $96 \pm 3 b$ & \multicolumn{2}{|c|}{$105 \pm 2$} \\
\hline 2010 & $130 \pm 4 a$ & $105 \pm 3 b$ & $105 \pm 3 b$ & $105 \pm 4 b$ & \multicolumn{2}{|c|}{$111 \pm 2$} \\
\hline \multicolumn{7}{|c|}{$\begin{array}{l}\text { External canopy surface } \\
\left.\text { area ( } \mathrm{m}^{2} / \mathrm{vine}\right)\end{array}$} \\
\hline 2008 & $4.50 \pm 0.18 d$ & $6.45 \pm 0.22 c$ & $9.64 \pm 0.39 b$ & $13.08 \pm 0.83 a$ & \multicolumn{2}{|c|}{$8.42 \pm 0.53$} \\
\hline 2009 & $4.51 \pm 0.16 \mathrm{~d}$ & $7.15 \pm 0.18 c$ & $10.64 \pm 0.32 b$ & $14.21 \pm 0.39 a$ & \multicolumn{2}{|c|}{$9.13 \pm 0.55$} \\
\hline 2010 & $4.44 \pm 0.09 d$ & $7.05 \pm 0.14 c$ & $10.29 \pm 0.33 b$ & $14.43 \pm 0.38 a$ & \multicolumn{2}{|c|}{$9.05 \pm 0.56$} \\
\hline \multicolumn{7}{|c|}{$\begin{array}{l}\text { External canopy surface area } \\
\text { per unit row length }\left(\mathrm{m}^{2} / \mathrm{m}\right)\end{array}$} \\
\hline 2008 & $4.92 \pm 0.19 \mathrm{a}$ & $3.53 \pm 0.12 b$ & $3.52 \pm 0.14 b$ & $3.58 \pm 0.23 b$ & $3.70 \pm 0.17$ & $4.07 \pm 0.17$ \\
\hline 2009 & $4.93 \pm 0.17 \mathrm{a}$ & $3.91 \pm 0.10 b$ & $3.88 \pm 0.12 b$ & $3.89 \pm 0.11 b$ & $4.17 \pm 0.11$ & $4.14 \pm 0.14$ \\
\hline 2010 & $4.86 \pm 0.10 \mathrm{a}$ & $3.85 \pm 0.07 b$ & $3.75 \pm 0.12 b$ & $3.95 \pm 0.10 b$ & $4.04 \pm 0.11$ & $4.17 \pm 0.12$ \\
\hline \multicolumn{7}{|c|}{ Canopy volume ( $\left.\mathrm{m}^{3} / v i n e\right)$} \\
\hline 2008 & $2.12 \pm 0.14 \mathrm{c}$ & $2.21 \pm 0.16 \mathrm{c}$ & $3.29 \pm 0.30 b$ & $4.76 \pm 0.54 \mathrm{a}$ & \multicolumn{2}{|c|}{$3.10 \pm 0.22$} \\
\hline 2009 & $2.14 \pm 0.14 \mathrm{c}$ & $2.62 \pm 0.13 c$ & $3.99 \pm 0.22 b$ & $5.17 \pm 0.30 \mathrm{a}$ & \multicolumn{2}{|c|}{$3.48 \pm 0.20$} \\
\hline 2010 & $2.12 \pm 0.09 c$ & $2.69 \pm 0.09 c$ & $3.91 \pm 0.22 b$ & $5.61 \pm 0.31 \mathrm{a}$ & \multicolumn{2}{|c|}{$3.58 \pm 0.22$} \\
\hline \multicolumn{7}{|c|}{$\begin{array}{l}\text { Canopy volume per unit } \\
\text { row length }\left(\mathrm{m}^{3} / \mathrm{m}\right)\end{array}$} \\
\hline 2008 & $2.32 \pm 0.16 \mathrm{a}$ & $1.21 \pm 0.09 b$ & $1.20 \pm 0.11 b$ & $1.30 \pm 0.15 b$ & $1.38 \pm 0.13$ & $1.63 \pm 0.13$ \\
\hline 2009 & $2.34 \pm 0.15 a$ & $1.44 \pm 0.07 b$ & $1.46 \pm 0.08 b$ & $1.41 \pm 0.08 \mathrm{~b}$ & $1.66 \pm 0.10$ & $1.66 \pm 0.12$ \\
\hline 2010 & $2.32 \pm 0.10 \mathrm{a}$ & $1.47 \pm 0.05 b$ & $1.43 \pm 0.08 b$ & $1.53 \pm 0.09 b$ & $1.63 \pm 0.09$ & $1.75 \pm 0.10$ \\
\hline \multicolumn{7}{|c|}{$\begin{array}{l}\text { Canopy surface area: } \\
\text { volume ratio }\left(\mathrm{m}^{2} / \mathrm{m}^{3}\right)\end{array}$} \\
\hline 2008 & $2.19 \pm 0.10 b$ & $3.01 \pm 0.13 a$ & $3.07 \pm 0.14 a$ & $3.09 \pm 0.32 a$ & $3.02 \pm 0.19$ & $2.66 \pm 0.09$ \\
\hline 2009 & $2.17 \pm 0.09 b$ & $2.77 \pm 0.07 \mathrm{a}$ & $2.70 \pm 0.07 \mathrm{a}$ & $2.80 \pm 0.08 a$ & $2.60 \pm 0.07$ & $2.62 \pm 0.08$ \\
\hline 2010 & $2.12 \pm 0.05 b$ & $2.64 \pm 0.05 a$ & $2.68 \pm 0.08 \mathrm{a}$ & $2.62 \pm 0.08 \mathrm{a}$ & $2.55 \pm 0.07$ & $2.47 \pm 0.07$ \\
\hline \multicolumn{7}{|c|}{$\begin{array}{l}\text { Fruit zone light } \\
\text { (\% ambient) }\end{array}$} \\
\hline 2008 & $3.9 \pm 1.2 b$ & $18.2 \pm 3.5 \mathrm{a}$ & $23.8 \pm 3.4 \mathrm{a}$ & $13.7 \pm 3.0 \mathrm{a}$ & $18.7 \pm 2.8$ & $13.1 \pm 2.1$ \\
\hline 2009 & $1.9 \pm 0.6 b$ & $9.4 \pm 1.9 \mathrm{a}$ & $9.1 \pm 2.4 \mathrm{a}$ & $11.0 \pm 2.2 \mathrm{a}$ & $8.0 \pm 1.4$ & $7.7 \pm 1.6$ \\
\hline 2010 & $0.7 \pm 0.2 b$ & $3.4 \pm 0.9 a b$ & $3.7 \pm 0.7 \mathrm{ab}$ & $6.0 \pm 1.9 a$ & $4.1 \pm 1.0$ & $2.7 \pm 0.6$ \\
\hline
\end{tabular}

a Values are listed for both row spacings only when the main effect is significant $(p<0.05)$.

${ }^{b}$ Values show means \pm SE $(n=12)$. Different letters within rows indicate significant differences by Duncan's new multiple range test $(p<0.05)$; absence of letters indicates no significant difference. 
Compared with the pronounced effect of within-row spacing, the influence on yield of row spacing was minor: during the last four years of this study, when the vines were fully productive, planting vines to $2.44 \mathrm{~m}$ rather than $2.74 \mathrm{~m}$ between rows returned an extra crop of $2 \mathrm{t} / \mathrm{ha}$ per year, which would add $\$ 400 /$ ha to a grower's annual revenue. These simple estimates do not take into account the costs of planting material, hardware, and labor for vineyard establishment and vine training, which would tend to decrease with decreasing planting density. Moreover, after vines are transitioned to machine pruning, annual production costs would be virtually independent of within-row spacing but would remain inversely proportional to between-row spacing. Although the planting density with the highest cumulative vineyard yield over the first six cropping seasons was $2.44 \mathrm{~m}$ between rows and $1.83 \mathrm{~m}$ within rows, the large canopy size of these mechanically-pruned juice grapes rendered the narrower row spacing somewhat challenging for tractor traffic.

The high $\mathrm{K}$ and $\mathrm{pH}$ in the juice from $0.91-\mathrm{m}$ vines at both $80 \%$ veraison and harvest is consistent with the numerous dead leaves in the dense canopy at veraison, the low nutrient content of those leaves, and the vigorous shoots of these vines. Excessively high canopy density, it seems, leads to a vicious cycle whereby vines shed their interior source leaves and recycle their nutrients to sinks such as berries and shoot tips. The latter continue to grow in search of more light at the expense of crop production and fruit quality (Keller and Koblet 1995a). Moreover, the very high sink strength of grapes undergoing veraison (Keller et al. 2015b) can be problematic when leaves are dying at the same time. The correlation between juice $\mathrm{K}$ and $\mathrm{pH}$ each year supports the idea that the high $\mathrm{K}$ concentrations in fruit from the low-yielding 0.91-m vines led to an increase in juice $\mathrm{pH}$. These results, combined with the marked differences in canopy density and canopy light attenuation

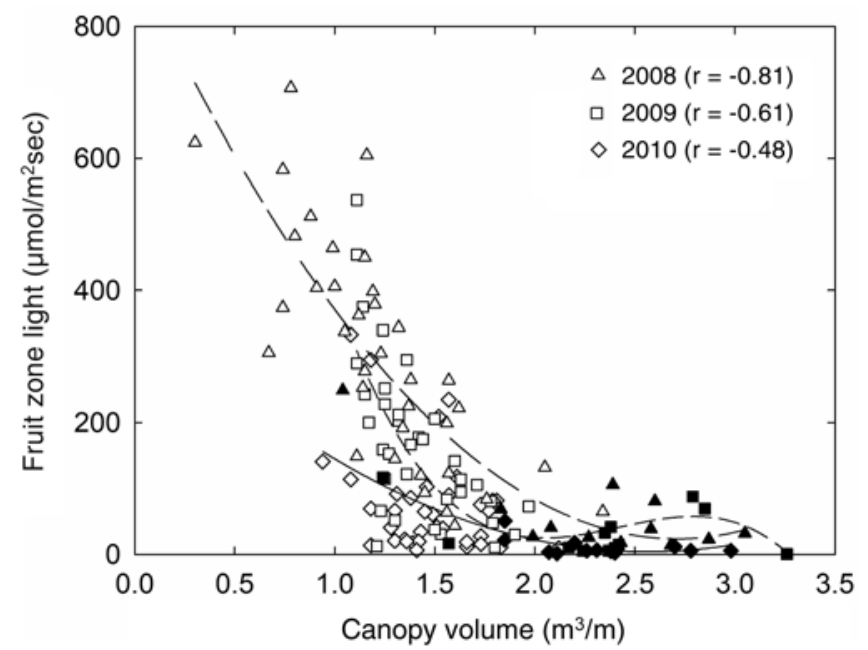

Figure 7 Association over three years between canopy volume per unit row length and light penetration into the fruit zone of mechanically-pruned Concord juice grapes in a vineyard in southeastern Washington planted in 2003 at four different within-row distances (filled symbols represent vines planted at $0.91 \mathrm{~m}$, open symbols represent vines planted at 1.83 , 2.74 , and $3.66 \mathrm{~m}$ ) and two between-row distances $(2.44 \mathrm{~m}$ and $2.74 \mathrm{~m}$; data pooled for lack of significant differences). between $0.91-\mathrm{m}$ vines and the vines spaced 1.83, 2.74, and $3.66 \mathrm{~m}$ apart, suggest that high fruit $\mathrm{K}$, and hence high $\mathrm{pH}$, result from low light in the canopy interior (Smart et al. 1985). The $\mathrm{K}^{+}$ions may have substituted for protons in the berry cell vacuoles, thus driving up the $\mathrm{pH}$ (Boulton 1980). In principle, $\mathrm{K}^{+}$could also have formed salts with, and precipitated, juice organic acids during sample preparation for chemical analysis, but we observed no sign of such precipitation. However, high $\mathrm{K}^{+}$concentrations may lead to precipitation of K-tartrate during juice storage (Morris et al. 1983).

However, the difference of $\sim 4 \mathrm{mg} \mathrm{K}$ between exterior and interior leaves in 2009 was only marginally significant $(p=0.09)$ due to high variability among samples. If one accepts this change as realistic, and assuming a death rate of $25 \%$ for the $\sim 1000$ leaves on the $0.91-\mathrm{m}$ vines (estimated from data in Keller et al. 2004), 1 $\mathrm{g} \mathrm{K}$ would have been available for export via the phloem from the senescing leaves. Because in 2009 the $0.91-\mathrm{m}$ vines had $\sim 3000$ berries per plant, each berry could have received a dose of $\sim 0.33 \mathrm{mg} \mathrm{K}$. However, these vines had $\sim 0.7 \mathrm{mg}$ more $\mathrm{K}$ per berry than the more widely spaced vines. Consequently, nutrient remobilization from senescing leaves could have accounted for $\sim 50 \%$ of the increased berry $\mathrm{K}$ in the high-density vines. This conclusion must be viewed as tentative; a more intense sampling campaign would be necessary to quantify the extent of $\mathrm{K}$ redistribution from senescing leaves. Moreover, while $\sim 75 \%$ of the $\mathrm{K}$ remained in the dead leaves, greater amounts and/ or proportions of carbon and mineral nutrients other than $\mathrm{K}$ (especially $\mathrm{N}, \mathrm{P}, \mathrm{Ca}$, and $\mathrm{S}$, but also $\mathrm{Mg}$ and some $\mathrm{Mn}, \mathrm{Cu}$, and $\mathrm{B}$ ) were remobilized from the interior leaves. Among these, the phloem-mobile $\mathrm{N}, \mathrm{P}, \mathrm{S}, \mathrm{Mg}, \mathrm{Cu}$, and $\mathrm{B}$ are known to accumulate in ripening grape berries (Rogiers et al. 2006, Keller 2020), but these nutrients were not measured in the berries in our study. Although their fate remains unknown, it seems likely that at least a portion of the recycled nutrients

\begin{tabular}{|c|c|c|c|c|}
\hline eaf position & Exterior & Interior & Change $(\%)^{a}$ & $p$ \\
\hline W (g) & $2.74 \pm 0.14^{b}$ & $0.95 \pm 0.06$ & -65 & $<0.001$ \\
\hline hl (SPAD) & $53 \pm 1$ & $0 \pm 0$ & -100 & $<0.001$ \\
\hline (g) & $1.27 \pm 0.07$ & $0.41 \pm 0.02$ & -68 & $<0.001$ \\
\hline (mg) & $55.4 \pm 5.4$ & $8.0 \pm 0.7$ & -86 & $<0.001$ \\
\hline (mg) & $5.01 \pm 0.28$ & $0.87 \pm 0.06$ & -83 & $<0.001$ \\
\hline$(\mathrm{mg})$ & $15.0 \pm 1.7$ & $11.3 \pm 1.2$ & -25 & 0.09 \\
\hline a (mg) & $62.5 \pm 2.8$ & $22.5 \pm 1.7$ & -64 & $<0.001$ \\
\hline$g(m g)$ & $9.76 \pm 0.51$ & $4.44 \pm 0.37$ & -55 & $<0.001$ \\
\hline$(\mathrm{mg})$ & $5.12 \pm 0.30$ & $0.84 \pm 0.09$ & -84 & $<0.001$ \\
\hline$e(\mu g)$ & $556.1 \pm 47.2$ & $443.7 \pm 28.7$ & -20 & 0.06 \\
\hline$n(\mu \mathrm{g})$ & $498.2 \pm 72.5$ & $183.4 \pm 41.7$ & -63 & 0.001 \\
\hline$(\mu \mathrm{g})$ & $62.9 \pm 2.7$ & $38.7 \pm 2.9$ & -39 & $<0.001$ \\
\hline$n(\mu g)$ & $33.8 \pm 3.0$ & $24.7 \pm 2.0$ & -27 & 0.02 \\
\hline $\mathrm{u}(\mu \mathrm{g})$ & $20.3 \pm 1.3$ & $10.8 \pm 1.0$ & -47 & $<0.001$ \\
\hline
\end{tabular}

aPercentage change from exterior to interior leaves.

${ }^{b}$ All values refer to mean content (i.e., amount per leaf $) \pm \operatorname{SE}(n=12)$. 
was partitioned to newly unfolding leaves at the canopy exterior to support continued shoot growth.

\section{Conclusions}

The present study demonstrated that there is no benefit in terms of cropping potential and fruit quality when juice grapes are planted at high density in irrigated and highly mechanized vineyards. On the contrary, the high canopy density and poor light microclimate of closely-spaced vines adversely impacted their yield potential and juice $\mathrm{pH}$. Vines planted at high density $(0.91 \mathrm{~m}$ within rows and $2.44 \mathrm{~m}$ or $2.74 \mathrm{~m}$ between rows) competed for access to sunlight rather than for soil water and nutrients. Their low yield was a consequence of reduced cluster initiation and fruit set, which resulted in fewer clusters/vine, fewer berries/cluster, and lower cluster weights. Their continued, vigorous shoot growth and high juice $\mathrm{K}$ and $\mathrm{pH}$ suggest that nutrients remobilized from dying leaves in the canopy interior were transported to the shoot tips and clusters. High-pH juice may require acid addition, which would increase the TA above that in juice derived from vines spaced further apart. Consequently, the high planting density compromised both yield and quality of the juice grapes grown in this study. Although the vines planted $0.91 \mathrm{~m}$ apart did fill the cordon more quickly than the more widely spaced vines, this advantage translated into a gain in yield only in the first cropping season. This early benefit, however, did not nearly balance the subsequent loss in vine productivity. Over the first eight years after planting, vines spaced between $1.83 \mathrm{~m}$ and $3.66 \mathrm{~m}$ within rows, and either $2.44 \mathrm{~m}$ or $2.74 \mathrm{~m}$ between rows, had similar crop yields per unit vineyard surface area and did not differ in terms of fruit quality. Based on the present results, juice grape growers may be ill-advised to increase planting density or apply management strategies that maximize canopy development: the goal is to maximize the production of high-quality fruit, rather than that of leaves. While it is important to develop and maintain a moderately vigorous canopy early in the growing season for optimum, sustained Concord productivity, overly vigorous, crowded canopies clearly are undesirable and may even be counterproductive. The present results suggest that vineyard designs (whether planting densities or trellis/training systems) and management practices that result in leaf death at veraison should be avoided to prevent undesirable increases in juice $\mathrm{pH}$. Adequate planting distances coupled with mechanical pruning and judicious irrigation and plant nutrition strategies seem to meet the requirements of modern juice grape production.

\section{Literature Cited}

Archer E and Strauss HC. 1991. The effect of vine spacing on the vegetative and reproductive performance of Vitis vinifera L. (cv. Pinot noir). S Afr J Enol Vitic 12:70-76.

Bates T and Morris J. 2009. Mechanical cane pruning and crop adjustment decreases labor costs and maintains fruit quality in New York 'Concord' grape production. HortTechnology 19:247-253.

Bernizzoni F, Gatti M, Civardi S and Poni S. 2009. Long-term performance of Barbera grown under different training systems and within-row vine spacings. Am J Enol Vitic 60:339-348.
Boulton R. 1980. The relationships between total acidity, titratable acidity and $\mathrm{pH}$ in grape tissues. Vitis 19:113-120.

Clingeleffer PR. 1984. Production and growth of minimal pruned Sultana vines. Vitis 23:42-54.

Elsner MM, Cuo L, Voisin N, Deems JS, Hamlet AF, Vano JA, Mickelson KEB, Lee SY and Lettenmaier DP. 2010. Implications of 21st century climate change for the hydrology of Washington State. Clim Change 102:225-260.

Gladstone EA and Dokoozlian NK. 2003. Influence of leaf area density and trellis/training system on the microclimate within grapevine canopies. Vitis 42:123-131.

Harbertson JF and Harwood ED. 2009. Partitioning of potassium during commercial-scale red wine fermentations and model wine extractions. Am J Enol Vitic 60:43-49.

Hedberg PR and Raison J. 1982. The effect of vine spacing and trellising on yield and fruit quality of Shiraz grapevines. Am J Enol Vitic 33:20-30.

Huber F, Röckel F, Schwander F, Maul E, Eibach R, Cousins P and Töpfer R. 2016. A view into American grapevine history: Vitis vinifera cv. 'Sémillon' is an ancestor of 'Catawba' and 'Concord'. Vitis 55:53-56.

Intrieri C. 1987. Experiences on the effect of vine spacing and trellistraining system on canopy micro-climate, vine performance and grape quality. Acta Hortic 206:69-88.

Intrieri C, Poni S, Lia G and Gomez del Campo M. 2001. Vine performance and leaf physiology of conventionally and minimally pruned Sangiovese grapevines. Vitis 40:123-130.

Keller M. 2020. The Science of Grapevines. 3rd ed. Elsevier Academic Press, London, UK.

Keller M and Koblet W. 1995a. Dry matter and leaf area partitioning, bud fertility and second season growth of Vitis vinifera L.: Responses to nitrogen supply and limiting irradiance. Vitis 34:77-83.

Keller M and Koblet W. 1995b. Stress-induced development of inflorescence necrosis and bunch-stem necrosis in Vitis vinifera L. in response to environmental and nutritional effects. Vitis 34:145-150.

Keller M, Kummer M and Vasconcelos MC. 2001. Reproductive growth of grapevines in response to nitrogen supply and rootstock. Aust J Grape Wine Res 7:12-18.

Keller M, Mills LJ, Wample RL and Spayd SE. 2004. Crop load management in Concord grapes using different pruning techniques. Am J Enol Vitic 55:35-50.

Keller M, Tarara JM and Mills LJ. 2010. Spring temperatures alter reproductive development in grapevines. Aust J Grape Wine Res $16: 445-454$.

Keller M, Deyermond LS and Bondada BR. 2015a. Plant hydraulic conductance adapts to shoot number but limits shoot vigour in grapevines. Funct Plant Biol 42:366-375.

Keller M, Zhang Y, Shrestha PM, Biondi M and Bondada BR. 2015b. Sugar demand of ripening grape berries leads to recycling of surplus phloem water via the xylem. Plant Cell Environ 38:1048-1059.

Koblet W, Candolfi-Vasconcelos MC, Zweifel W and Howell GS. 1994. Influence of leaf removal, rootstock, and training system on yield and fruit composition of Pinot noir grapevines. Am J Enol Vitic 45:181-187.

Miller DP and Howell GS. 1998. Influence of vine capacity and crop load on canopy development, morphology, and dry matter partitioning in Concord grapevines. Am J Enol Vitic 49:183-190.

Morris JR and Cawthon DL. 1981. Yield and quality response of Concord grapes (Vitis labrusca L.) to mechanized vine pruning. Am J Enol Vitic 32:280-282.

Morris JR, Sims CA and Cawthon DL. 1983. Effects of excessive potassium levels on $\mathrm{pH}$, acidity and color of fresh and stored grape juice. Am J Enol Vitic 34:35-39. 
Mullins MG, Bouquet A and Williams LE. 1992. Biology of the Grapevine. Cambridge University Press, Cambridge, UK.

Poni S, Tombesi S, Palliotti A, Ughini V and Gatti M. 2016. Mechanical winter pruning of grapevine: Physiological bases and applications. Sci Hortic 204:88-98.

Possingham JV. 1994. New concepts in pruning grapevines. Hortic Rev 16:235-254.

Reynolds AG and Wardle DA. 1994. Impact of training system and vine spacing on vine performance and berry composition of Seyval blanc. Am J Enol Vitic 45:444-451.

Reynolds AG and Vanden Heuvel JE. 2009. Influence of grapevine training systems on vine growth and fruit composition: A review. Am J Enol Vitic 60:251-268.

Reynolds AG, Wardle DA and Naylor AP. 1996. Impact of training system, vine spacing, and basal leaf removal on Riesling. Vine performance, berry composition, canopy microclimate, and vineyard labor requirements. Am J Enol Vitic 47:63-76.

Reynolds AG, Wardle DA, Cliff MA and King M. 2004a. Impact of training system and vine spacing on vine performance, berry composition, and wine sensory attributes of Seyval and Chancellor. Am J Enol Vitic 55:84-95.

Reynolds AG, Wardle DA, Cliff MA and King M. 2004b. Impact of training system and vine spacing on vine performance, berry composition, and wine sensory attributes of Riesling. Am J Enol Vitic 55:96-103.

Rogiers SY, Greer DH, Hatfield JM, Orchard BA and Keller M. 2006. Mineral sinks within ripening grape berries (Vitis vinifera L.). Vitis $45: 115-123$
Shaulis NJ. 1982. Responses of grapevines and grapes to spacing of and within canopies. In Proceedings of the Grape and Wine Centennial Symposium. Webb AD and Amerine MA (eds.), pp. 353-361. University of California, Davis.

Shaulis N and Kimball K. 1955. Effect of plant spacing on growth and yield of Concord grapes. Proc Am Soc Hortic Sci 66:192-200.

Smart RE, Shaulis NJ and Lemon ER. 1982a. The effect of Concord vineyard microclimate on yield. I. The effects of pruning, training, and shoot positioning on radiation microclimate. Am J Enol Vitic 33:99-108.

Smart RE, Shaulis NJ and Lemon ER. 1982b. The effect of Concord vineyard microclimate on yield. II. The interrelations between microclimate and yield expression. Am J Enol Vitic 33:109-116.

Smart RE, Robinson JB, Due GR and Brien CJ. 1985. Canopy microclimate modification for the cultivar Shiraz. II. Effects on must and wine composition. Vitis 24:119-128.

Tarara JM and Ferguson JC. 2006. Two algorithms for variable power control of heat-balance sap flow gauges under high flow rates. Agron J 98:830-838.

Turkington CR, Peterson JR and Evans JC. 1980. A spacing, trellising, and pruning experiment with Muscat Gordo Blanco grapevines. Am J Enol Vitic 31:298-302.

Winkler AJ. 1959. The effect of vine spacing at Oakville on yields, fruit composition, and wine quality. Am J Enol Vitic 10:39-43.

Winkler AJ. 1969. Effect of vine spacing in an unirrigated vineyard on vine physiology, production and wine quality. Am J Enol Vitic 20:7-15. 